Ethiopian Journal of Environmental Studies and Management EJESM Vol. 5 no.4 (Suppl.1) 2012

\title{
STRUCTURAL PATTERN OF MOBILE PHONE USAGE IN LAGOS METROPOLIS, NIGERIA OSOBA, S. B.
}

http://dx.doi.org/10.4314/ejesm.v5i4.S9

\author{
Received 20th August 2012; accepted 4th October 2012
}

\begin{abstract}
The wide use of the Global System for Mobile communication (GSM) and its influence on various aspects of the society is yet to be empirically investigated. This paper examined the relationship between GSM usage and socio-economic characteristic (sex, marital status, age, education, income, occupation and employment) of the GSM-owners. The study sample consisted of 2,500 households in the study area. Systematic sampling technique was used to select every tenth building on the identified streets. In a multi-family dwelling, random sampling was used to select one household. The data collected were analysed using simple frequency contain form of cross tabulation to compute the number of GSM calls made and the number of call received by GSMowners within Lagos metropolis. The study reveals that over $80 \%$ of GSM phone calls were made in areas with industrial concentration and commercial activities. The paper recommended that transport planners in Lagos need to develop alternative intra-city transport systems. This can be achieved through a shift to the development of other land transport systems by policy makers.
\end{abstract}

Key words: GSM, Intra-city transport, Travel pattern, Socio-economic characteristics

\section{Introduction}

Spatial interaction in urban setting could be of at least two types namely; those that involve physical contacts like day to day movements of people and those that do not require such contact like telephoning. This is because they represent both a function and a process (Ayeni, 1979, Axhausen and Gariling, 1992). They functions as long as they perform the duty of maintaining the status quo in the spatial relation of different part of the city, while they are processes when changes in their volume, intensity and direction come to determine the pattern of growth and organization of the spatial structure of the city.The socio-economic and cultural growth of any nation can be measured through the efficiency of its transportation network and its judicious provision of telecommunication facilities.

Telecommuting takes place in Lagos metropolis with the relatively recent telecommunication technology GSM used to substitute the home office business, social and recreational trips. This has become a weapon in conserving physical energy as well as to avoid the constant transportation chaos experienced (congestion, pollution, accident). It should be noted that, apart from the use of GSM for calls, the electronic messages and the internet or computer messages serve as alternative to travels in the city. More so, telecommuting can take place under various organisations depending on the nature of the job, the personnel involved as well as the organization and socio cultural settings. In Lagos metropolis for instance, telecommuting is performed when an employee of the state ministry telecommutes with his counterparts either at Federal, State or Local levels as well as private organizations of a pressing issue.

There exists a strong relationship between movement pattern and the location distribution of activities over geographic space (Goddard, 1970). However, what is unclear is the relationship between telephone interaction pattern and the location of activities within the urban or sub-urban centres. Fundamental to this relationship is the role and impact of telecommuting technologies such as the telephone (cherry, 1970 and Clark, 1973). This relationship, however, is determined by certain underlying variables, which are neither similar nor transferable from the developed areas of the world to the developing areas, particularly, the African countries (Adeniji-Soji, 1996, 2000). Abler (1968), Clark (1973) and Elliot - Hurst (1974) recongised the geographical and socialeconomic importance of communication flow and its role as agent of change within the spatial system.

Lagos metropolis is being considered as a 
study area because it has an increasing demand of GSM usage. The expectation is that the use of GSM will reduce this congestion by affecting the travel bahaviour of people. Also it is the commercial capital of Nigeria and it stands to benefit from the development of telecommunication especially GSM which can ease the ever-growing transportation complexities and problems. The justification for this study is that GSM is a notable innovation in information communication technology, ICT, industry and its effect on spatial interactions needs to be examined.

\section{Methodology \\ Study Area}

Nigeria is located in the Western part of Africa, bordering the Gulf of Guinea, lying between latitudes $4^{\circ} 20^{1}$ and $14^{0} 30^{1}$ east of Greenwich (Adeleke, 2003). Lagos State lies approximately between longitudes $2^{0} 42 \mathrm{E}$ and $3^{\circ} 42 \mathrm{E}$ and latitudes $6^{\circ} 22 \mathrm{~N}$ and $6^{\circ} 52 \mathrm{~N}$. The 180 $\mathrm{km}$ long Atlantic coastline forms the Southern boundary of the state while its Northern and Eastern boundaries are shared with Ogun State. On the Western side, the Republic of Benin borders the boundary (Balogun et al., 1999).

Lagos Metropolis occupies, 2,910sq.km out of the 3,577 sq. $\mathrm{km}$ land area of Lagos Metropolitan Area. The local governments are Agege, Alimosho, Apapa, Amuwo-Odofin, EtiOsa, Ikeja, Ifako-Ijaiye, Kosofe, Lagos Island, Lagos Mainland, Surulere, Mushin, OshodiIsolo, Ojo and Somolu (Lagos State 2003 digest). 5.7 million people or 6.4 percent of the population of Nigeria (88.5 million people in 1991) live in Lagos State (Nigeria National Population Census, 1991). In 1997, Lagos State population was estimated at 6.9 million out of which Lagos Metropolitan Area has 5.2 million (Nigeria National Population Commission, 1997). The population of Lagos Metropolitan Area was estimated to be 12.9 million by 2000 and projected to be 24.5 million by 2015 (UN, 1996).

Despite the fact that Lagos metropolis is the largest commercial, economic and industrial centre in the country, its transportation and communication do not commensurate with its status as it has the worst in term of mobility and communication problems in Nigeria. There is no adequate, effective, efficient and inexpensive communications and means of mobility. And where available they are often too expensive, inefficient and considered as affair. Less than $10 \%$ of its population has access to efficient telecommunication facilities. In most cases and places where available it is grossly inefficient. Nigeria with GDP of US\$527 has a total teledensity penetration of $0.43 \%$ (fixed line generation is $0.4 \%$ for mobile line). Thirty percent of this alone is in the metropolis, yet inefficient and unreliable (source: Policy News magazine, vol. 6, n0. 16, April $16-22$, 2001). The working hypothesis postulated for testing is that, the usage of GSM in metropolitan Lagos is a function of socio-economic characteristics of residents.

\section{Data Collection}

Data were collected from primary and secondary sources. Systematic sampling technique was used to select every tenth building on the identified streets. In a multi-family dwelling, random sampling was used to select one household. Simple frequency count in form of cross tabulation to compute the number of GSM calls made and number of call received by GSM owned within Lagos metropolis, while Analysis of Variance (ANOVA) was used to test significant difference in the number of calls among the local government areas.

\section{Results and Discussion}

This section examines the structure and pattern of mobile phone usage in Lagos Metropolis. In order to achieve this, the variables (which are the data collected through administered questionnaires) are collected from the record of the GSM calls made (originated by the GSM-Owner) and the record of the GSM calls received within Lagos metropolis by the GSM owners while the simple frequency count in form of cross tabulation was used to compute the number of GSM calls made and the number of GSM calls received by GSM-owners within Lagos metropolis. This arrangement involves the listing of all the Local Government Areas in the columns of the cross tabulation as origins and also listing same in the rows of the cross tabulation as destination. The cells of the cross tabulation contain the actual number of calls from an origin and to a particular destination. 
Table 1 Average daily cumulative number of calls to and from each local government in the Lagos metropolis

\begin{tabular}{|c|c|c|c|c|c|c|c|c|c|c|c|c|c|c|c|c|c|c|}
\hline \multicolumn{2}{|c|}{ Day 1 Monday } & \multicolumn{16}{|c|}{ Area from where calls are made day 1} & \multirow[b]{2}{*}{$\%$} \\
\hline \multirow{17}{*}{$\begin{array}{l}\text { Area } \\
\text { where } \\
\text { calls are } \\
\text { received }\end{array}$} & & $\mathrm{AG}$ & OJ & AM & $\mathrm{AL}$ & AP & ET & IF & IK & $\mathrm{KO}$ & LI & LM & OS & SO & MU & SU & Total & \\
\hline & $\mathrm{AG}$ & 45 & 5 & 2 & 1 & 8 & 10 & 10 & 28 & 4 & & & 18 & & & 11 & 142 & 9.3 \\
\hline & OJ & & 5 & & & & & & 6 & 2 & & 2 & & 4 & 2 & & 21 & 1.9 \\
\hline & AM & 5 & 2 & 8 & 2 & 6 & & 2 & 6 & & & 4 & 5 & & & & 40 & 2.6 \\
\hline & $\mathrm{AL}$ & 7 & & 1 & 11 & 8 & 3 & & 2 & 1 & 7 & & & 2 & 1 & 6 & 49 & 3.2 \\
\hline & AP & & 4 & 4 & 3 & 18 & 10 & & 5 & 9 & 5 & 4 & 7 & 11 & 2 & 9 & 91 & 5.9 \\
\hline & ET & 2 & & 3 & 5 & 9 & 46 & 5 & 11 & 11 & 5 & 4 & 7 & 12 & 4 & 7 & 131 & 8.6 \\
\hline & IF & 3 & 2 & 2 & 4 & & 3 & 7 & 5 & 2 & 2 & & 8 & 4 & & 2 & 44 & 2.9 \\
\hline & IK & 23 & 4 & 7 & 9 & 27 & 28 & 7 & 105 & 6 & 23 & 6 & 17 & 14 & 3 & 35 & 314 & 20.5 \\
\hline & $\mathrm{KO}$ & 15 & 6 & 3 & 2 & 9 & 16 & 7 & 6 & 26 & 3 & 8 & 3 & 9 & 8 & 9 & 130 & 8.5 \\
\hline & LI & 6 & 3 & & 2 & 5 & 8 & 4 & 26 & 8 & 21 & 8 & 7 & 4 & 2 & 8 & 112 & 7.3 \\
\hline & $\mathrm{LM}$ & 2 & 4 & 3 & 2 & & 6 & 2 & 16 & 3 & 7 & 10 & 7 & 4 & 2 & 2 & 70 & 4.6 \\
\hline & OS & 7 & 4 & 4 & 7 & 6 & 8 & & 11 & 13 & 4 & 2 & 27 & 11 & 5 & 4 & 113 & 7.4 \\
\hline & $\mathrm{SO}$ & 2 & 5 & 1 & 2 & 6 & 9 & 4 & 22 & 4 & 2 & & 4 & 16 & 2 & 10 & 89 & 5.8 \\
\hline & $\mathrm{MU}$ & 4 & 2 & & 2 & & 6 & 9 & 7 & 2 & & & & & 11 & 1 & 44 & 2.9 \\
\hline & SU & 17 & 4 & 2 & 3 & 2 & 12 & 5 & 31 & 9 & 1 & 4 & 8 & 6 & 4 & 34 & 142 & 9.3 \\
\hline & Total & 138 & 50 & 40 & 55 & 104 & 165 & 62 & 287 & 100 & 80 & 52 & 118 & 97 & 46 & 138 & 1532 & \\
\hline & $\%$ & 9.0 & 3.3 & 2.6 & 3.6 & 6.8 & 10.8 & 4.0 & 18.7 & 6.5 & 5.2 & 3.4 & 7.7 & 6.3 & 3.0 & 9.0 & & \\
\hline
\end{tabular}

Abbreviations: $\mathrm{AG}=$ Agege OJ = Ojo AM = Amuwo-Odofin $;$ AL = Alimoso AP - Apapa ET = EtiOsa; IF = Ifako-Ijaye; IK = Ikeja; KO = Kosofe; LI = Lagos Island; LM Lagos Mainland; OS = Oshodi-

Isolo; $\mathrm{SO}=$ Somolu; $\mathrm{MU}=$ Mushin; $\mathrm{SU}=$ Surulere

Table 1 shows the pattern of mobile phone usage among the residents of the fifteen Local Governments Areas that constitute Lagos metropolis. Going through where calls are made and areas where calls are received on day 1, (Monday) Local Government Areas with the highest calls are Ikeja (19\%); followed by EtiOsa (11\%), Agege (9\%) Surulere (9\%) OshodiIsolo (8\%), Apapa (7\%) Kosofe (7\%), Somolu (7\%) and Lagos Island (6\%). These Local Governments accounted for almost $80 \%$ of all the calls made while the remaining six Local Government areas accounted for $20 \%$ of all calls made. These Local Government Areas are Ojo recording 4\%, Ifako-Ijaye (4\%), Mushin (4\%), Lagos Mainland (4\%) and Amuwo-Odofin (3\%). Similarly, the same nine Local Government areas also accounted for almost $80 \%$ of all the calls received in the area with Ikeja recording $21 \%$ of the total, followed by Agege (9\%), Kosofe (9\%) Eti-Osa (9\%), Surulere (9\%), Oshodi-Isolo (7\%), Lagos-Island (7\%), Apapa (6\%) and Somolu (6\%) while the same remaining six Local Government Areas accounted for $20 \%$ of all the calls received. These Local Government Areas are Alimoso recording 4\%; Lagos Island (4\%), Amuwo-Odofin (3\%), Mushin (3\%) Ifako-Ijaye $(3 \%)$ and Ojo (2\%).

From the above, it is obvious that calls are made and received mainly by the Local Governments with high concentration of industrial and commercial activities while areas with low level of industrial and commercial activities have low level of calls made and received. 
Table 2 Average daily cumulative number of calls to and from each Local Government in the Lagos metropolis

\begin{tabular}{|c|c|c|c|c|c|c|c|c|c|c|c|c|c|c|c|c|c|c|}
\hline \multicolumn{2}{|c|}{ Day 2 Tuesday } & \multicolumn{16}{|c|}{ Area from where calls are made day 2} & \\
\hline \multirow{18}{*}{$\begin{array}{l}\text { Area } \\
\text { where } \\
\text { calls are } \\
\text { received }\end{array}$} & & AG & OJ & $\overline{\mathrm{AM}}$ & $\mathrm{AL}$ & AP & ET & IF & IK & $\mathrm{KO}$ & LI & LM & OS & SO & $\mathrm{MU}$ & $\mathrm{SU}$ & Total & $\%$ \\
\hline & $\mathrm{AG}$ & 25 & 5 & 2 & 2 & & 6 & 4 & 28 & 7 & 11 & & 11 & 10 & 6 & 12 & 129 & 9.3 \\
\hline & OJ & 2 & 8 & 7 & & & & & & & 4 & 2 & 2 & 2 & 4 & 4 & 35 & 2.5 \\
\hline & $\mathrm{AM}$ & 5 & 2 & 10 & 3 & 3 & 2 & 4 & 2 & 4 & & 5 & 5 & 6 & & 9 & 60 & 4.3 \\
\hline & $\mathrm{AL}$ & 3 & & 1 & 5 & 6 & 4 & & 8 & 5 & 2 & 2 & 5 & 8 & 2 & 3 & 54 & 3.9 \\
\hline & $\mathrm{AP}$ & 8 & 4 & & & 11 & 9 & 1 & 6 & & & 2 & & 7 & 6 & 2 & 56 & 6.0 \\
\hline & ET & 6 & & 2 & 1 & 4 & 39 & 2 & 20 & 9 & 6 & 5 & 14 & 8 & 5 & 9 & 130 & 9.3 \\
\hline & IF & 2 & & & & 2 & 1 & 3 & 4 & 4 & 2 & 5 & 2 & 2 & 2 & & 29 & 2.1 \\
\hline & IK & 11 & 16 & 4 & 6 & & 22 & 8 & 79 & 18 & 2 & 8 & 19 & 13 & 6 & 12 & 224 & 16.1 \\
\hline & KO & 9 & 1 & & & 2 & 5 & 2 & 21 & 19 & 3 & 3 & 5 & 16 & 3 & 12 & 101 & 7.3 \\
\hline & LI & 8 & & & 4 & 12 & 10 & & 14 & 12 & 9 & & 6 & 5 & 2 & 6 & 88 & 6.3 \\
\hline & LM & 4 & & & 1 & & 5 & 2 & 6 & 1 & 5 & 15 & 4 & 2 & & 6 & 51 & 3.7 \\
\hline & OS & 8 & 2 & 2 & & 10 & 11 & & 22 & 14 & 10 & 2 & 32 & 15 & 8 & 7 & 143 & 10.3 \\
\hline & $\mathrm{SO}$ & 4 & 5 & 2 & 2 & 4 & 4 & 2 & 15 & 6 & 7 & 4 & 13 & 22 & & 13 & 103 & 7.4 \\
\hline & $\mathrm{MU}$ & 7 & 4 & & 1 & 5 & & & 8 & & 9 & 2 & & 11 & 4 & 3 & 54 & 3.9 \\
\hline & SU & 9 & 4 & 4 & 4 & 12 & 4 & 4 & 16 & 7 & 12 & 4 & 15 & 10 & 10 & 19 & 134 & 9.6 \\
\hline & Total & 111 & 51 & 34 & 29 & 71 & 122 & 32 & 249 & 106 & 82 & 59 & 133 & 137 & 58 & 117 & 1391 & \\
\hline & $\%$ & 8.0 & 3.7 & 2.4 & 2.1 & 6.1 & 8.8 & 2.3 & 17.9 & 7.6 & 5.9 & 4.2 & 9.6 & $\begin{array}{l}9.8 \\
\end{array}$ & 4.2 & 8.4 & & \\
\hline
\end{tabular}

Abbreviations: $\mathrm{AG}=$ Agege $; \mathrm{OJ}=\mathrm{Ojo} ; \mathrm{AM}=$ Amuwo-Odofin $; \mathrm{AL}=$ Alimoso; $\mathrm{AP}-\mathrm{Apapa} ; \mathrm{ET}=\mathrm{Eti}-\mathrm{Osa} ; \mathrm{IF}=$ Ifako-Ijaye; IK = Ikeja; KO = Kosofe; LI = Lagos Island; LM Lagos Mainland; OS = Oshodi-Isolo; SO = Somolu; $\mathrm{MU}=$ Mushin; $\mathrm{SU}=$ Surulere

Table 2 reveals the pattern of mobile phone usage among the residents of the fifteen Local Government Areas that constitute Lagos Metropolis. Going through where calls are made and received on day 2, (Tuesday), the highest proportion of calls made are in Ikeja accounting for $18 \%$, Ikeja is followed by Somolu (19\%), Oshodi $(10 \%)$, Eti-Osa (9\%), Agege (8\%), Surulere (8\%), Kosofe (8\%) and Apapa (6\%) while the remaining six Local Government areas have the least proportion of calls made. These Local Government areas are Ojo (4\%); Lagos Mainland (4\%), Mushin (4\%); Amuwo-Odofin (3\%), Ifako-Ijaye (2\%) and Alimoso (2\%). In a similar manner, the same Local Government Areas that have high proportion of calls made also have the high proportion of calls received with Ikeja recording 16\%; followed by Surulere (10\%), Oshodi-Isolo (10\%), Agege (9\%),

Eti-Osa (9\%), Somolu (7\%), Kosofe (7\%), Apapa $(6 \%)$, and Lagos-Island $(6 \%)$ while the same remaining six Local Government Areas that have the least proportion of calls made also have the least proportion of calls received with Mushin accounting for $4 \%$, Lagos Mainland (4\%), Alimoso (4\%), Amuwo-odofin (4\%), Ojo (3\%) and IfakoIjaye $(2 \%)$.

From the above, the major reason for the high proportion of calls made and received among the Local Government Areas mentioned, could be attributed to the fact that these Local Government Areas have a high level of concentration of industrial and commercial activities while the Local Government areas with low level of calls made and received have low level concentration of industrial and commercial activities. 
Table 3 Average daily cumulative number of calls to and from each Local Government in the Lagos metropolis

\begin{tabular}{|c|c|c|c|c|c|c|c|c|c|c|c|c|c|c|c|c|c|c|}
\hline \multicolumn{2}{|c|}{ Day 3 Wednesday } & \multicolumn{16}{|c|}{ Area from where calls are made day 3} & \multirow[b]{2}{*}{$\%$} \\
\hline \multirow{17}{*}{$\begin{array}{l}\text { Area } \\
\text { where } \\
\text { calls are } \\
\text { received }\end{array}$} & & $\mathrm{AG}$ & OJ & $\mathrm{AM}$ & $\mathrm{AL}$ & $\mathrm{AP}$ & ET & IF & IK & $\mathrm{KO}$ & LI & LM & OS & SO & MU & SU & Total & \\
\hline & $\mathrm{AG}$ & 24 & 1 & 2 & & & 4 & 2 & 15 & 9 & 6 & 2 & 6 & 7 & 3 & 8 & 89 & 7.3 \\
\hline & OJ & 4 & 4 & & & 3 & & 5 & 4 & 2 & 2 & & 6 & 3 & 4 & 2 & 39 & 3.2 \\
\hline & $\mathrm{AM}$ & 5 & & 4 & & 2 & 1 & & 6 & 3 & & 1 & 9 & 2 & & 2 & 35 & 2.9 \\
\hline & $\overline{A L}$ & & & & 2 & & & 3 & 8 & 2 & 6 & & 6 & & 4 & 2 & 33 & 2.7 \\
\hline & AP & & & & 1 & 2 & 10 & 5 & & 7 & & 8 & 4 & 7 & 6 & & 9 & 6.8 \\
\hline & ET & 10 & 4 & & & 4 & 34 & & 17 & 8 & 11 & 2 & 8 & 7 & 4 & 8 & 117 & 9.6 \\
\hline & IF & & & & & 2 & 4 & & 8 & 6 & & 4 & 2 & 2 & & & 28 & 2.3 \\
\hline & IK & 21 & 1 & 5 & 9 & 12 & 14 & 6 & 41 & 13 & 5 & 1 & 20 & 13 & 7 & 16 & 184 & 15.1 \\
\hline & $\mathrm{KO}$ & 2 & 5 & 1 & 4 & 3 & & 2 & 10 & 17 & 4 & 3 & 9 & 7 & 7 & 7 & 81 & 6.6 \\
\hline & LI & 4 & 5 & 2 & & 1 & 8 & & 4 & 2 & 20 & 6 & 8 & 10 & 2 & 12 & 84 & 6.9 \\
\hline & LM & 7 & 2 & 4 & & & 11 & & 4 & 2 & 8 & 14 & 2 & 4 & 8 & 2 & 68 & 54.0 \\
\hline & OS & 22 & 3 & 3 & 8 & 1 & 23 & 8 & 7 & 8 & 7 & & 22 & 10 & 2 & 7 & 131 & 10.7 \\
\hline & $\mathrm{SO}$ & 13 & & & 3 & 5 & 7 & 5 & 10 & 7 & 3 & 8 & 7 & 18 & 13 & 11 & 110 & 9.0 \\
\hline & MU & 7 & 2 & 4 & 2 & 6 & 5 & 2 & 5 & 6 & 3 & & 6 & 4 & 2 & 4 & 58 & 4.0 \\
\hline & SU & 4 & & & 7 & 7 & 6 & & 7 & 10 & 14 & 2 & 19 & 2 & 4 & 23 & 105 & 8.6 \\
\hline & Total & 123 & 27 & 26 & 37 & 56 & 122 & 33 & 153 & 95 & 97 & 47 & 137 & 95 & 60 & 113 & 1221 & \\
\hline & $\%$ & 10.1 & 2.2 & 2.1 & 3.0 & 6.6 & 10.0 & 2.7 & 12.5 & 7.8 & 7.9 & 3.8 & 11.2 & 7.8 & 4.9 & 9.3 & & \\
\hline
\end{tabular}

Abbreviations: $\mathrm{AG}=$ Agege OJ = Ojo; $\mathrm{AM}=$ Amuwo-Odofin $; \mathrm{AL}=$ Alimoso AP - Apapa $;$ ET = Eti-Osa IF = Ifako-Ijaye; IK = Ikeja; KO = Kosofe; LI = Lagos Island; LM = Lagos Mainland; OS = Oshodi-Isolo; SO = Somolu; $\mathrm{MU}=$ Mushin; $\mathrm{SU}=$ Surulere

Table 3 shows the pattern of mobile phone usage among the residents of the fifteen Local Government Areas that constitute Lagos metropolis. Going through where calls are made and received on day 3, (Wednesday), the highest proportion of calls made are in Ikeja recording $13 \%$, followed by Oshodi (11\%), Agege 10\%), Eti-osa (10\%), Agege (9\%), Kosofe (8\%), Somolu (85), Lagos Island (8\%) and Apapa (7\%) while the remaining six Local Government Areas have the least proportion of calls made. These Local Government areas with the least proportion of calls made are Mushin (4\%), Lagos Island (4\%), Ifako-Ijaye (3\%), Alimoso (3\%), Amuwo-Odofin (2\%) and Ojo (2\%).

Similarly, it shows that the same Local Government areas that have high proportion of calls made also have the high proportion of calls received with Ikeja recording $15 \%$, followed by Oshodi-Isolo (11\%), Eti-Osa (10\%), Somolu (9\%), Surulere (9\%), Lagos Island (7\%), Kosofe (7\%), Apapa (7\%) and Agege (7\%) while the same remaining six Local Government areas have the least proportion of calls received. These Local Government areas are Mushin accounting for $4 \%$, followed by Lagos Mainland (4\%), Ifako-Ijaye (3\%), Alimoso (3\%), AmuwoOdofin (3\%) and Ojo (3\%).

From the above, it could be inferred that calls are made and received mainly by the Local Government Areas with the high concentration of industrial and commercial activities while areas with low level of commercial and industrial activities have low proportion of calls made and received. 
Table 4 Average daily cumulative number of calls to and from each Local Government in the Lagos metropolis

\begin{tabular}{|c|c|c|c|c|c|c|c|c|c|c|c|c|c|c|c|c|c|c|}
\hline \multicolumn{2}{|c|}{ Day 4 Thursday } & \multicolumn{16}{|c|}{ Area from where calls are made day 4} & \multirow[b]{2}{*}{$\%$} \\
\hline \multirow{18}{*}{$\begin{array}{l}\text { Area } \\
\text { where } \\
\text { calls are } \\
\text { received }\end{array}$} & & $\mathrm{AG}$ & $\mathrm{OJ}$ & $\overline{\mathrm{AM}}$ & $\mathrm{AL}$ & $\mathrm{AP}$ & ET & IF & IK & $\mathrm{KO}$ & LI & LM & OS & SO & MU & SU & Total & \\
\hline & $\mathrm{AG}$ & 20 & 2 & & 2 & 6 & 2 & & 8 & 3 & 6 & 5 & 7 & 1 & & 7 & 69 & 7.8 \\
\hline & OJ & 4 & 3 & 1 & & & & & 3 & 2 & & & 1 & 4 & & 2 & 20 & 2.3 \\
\hline & AM & 1 & 2 & 7 & & 2 & 7 & & & 2 & 6 & & 1 & & 2 & 2 & 32 & 3.6 \\
\hline & $\mathrm{AL}$ & 4 & 1 & 1 & 2 & 4 & & 3 & 2 & 4 & & 4 & 3 & & & & 28 & 3.2 \\
\hline & AP & 2 & & 5 & & 15 & 6 & 2 & 8 & & 7 & 4 & 8 & 3 & 5 & 3 & 68 & 7.7 \\
\hline & ET & 9 & 4 & 2 & 2 & 9 & 11 & 4 & 5 & 6 & 4 & 1 & 3 & 8 & 7 & 2 & 77 & 8.7 \\
\hline & IF & 2 & & 2 & 2 & 3 & 2 & 2 & 2 & & 3 & & 3 & & 2 & & 23 & 2.6 \\
\hline & IK & 14 & 2 & 4 & 4 & 10 & 9 & 4 & 23 & 4 & 11 & 8 & 7 & 9 & 4 & 14 & 127 & 14.3 \\
\hline & $\mathrm{KO}$ & 2 & 2 & 9 & & 2 & 5 & & 14 & 6 & 3 & & 1 & 12 & 4 & 7 & 67 & 7.5 \\
\hline & LI & & & & & 4 & 2 & 6 & 7 & 2 & 8 & & 2 & 3 & & 2 & 36 & 6.1 \\
\hline & LM & & & 2 & & & 1 & & 12 & 3 & 7 & 4 & 2 & 2 & & 8 & 41 & 4.6 \\
\hline & OS & 14 & 3 & 3 & 5 & 1 & 4 & & 14 & 4 & 11 & 9 & 12 & 6 & 2 & 2 & 90 & 10.1 \\
\hline & $\mathrm{SO}$ & 10 & 1 & 4 & & 2 & 8 & & 6 & 9 & 11 & 1 & 6 & 19 & & 10 & 87 & 9.8 \\
\hline & MU & 2 & & & 5 & & 2 & 4 & & & & 4 & 7 & 4 & 4 & 6 & 38 & 4.3 \\
\hline & SU & 4 & 3 & & 2 & 7 & 1 & 3 & 25 & 2 & 5 & 8 & 2 & & 8 & 15 & 85 & 9.6 \\
\hline & Total & 88 & 23 & 40 & 24 & 65 & 60 & 28 & 129 & 47 & 82 & 48 & 65 & 71 & 38 & 80 & 888 & \\
\hline & $\%$ & 9.9 & 2.6 & 4.5 & 2.7 & 7.3 & 6.8 & 3.2 & 14.5 & 6.3 & 9.2 & 4.4 & 7.3 & 8.0 & 4.3 & 9.0 & & \\
\hline
\end{tabular}

Abbreviations: $\mathrm{AG}=$ Agege OJ = Ojo AM = Amuwo-Odofin $; \mathrm{AL}=$ Alimoso AP - Apapa ET = EtiOsa; IF = Ifako-Ijaye; IK = Ikeja; KO = Kosofe; LI = Lagos Island; LM = Lagos Mainland; OS = OshodiIsolo; $\mathrm{SO}=$ Somolu; $\mathrm{MU}=$ Mushin; $\mathrm{SU}=$ Surulere

Table 4 reveals the pattern of mobile phone usage among the residents of the fifteen Local Government that constitute Lagos metropolis. Going through where calls are made and received on day 4 , (Thursday), the pattern of mobile phone calls made shows that a dominant proportion of $15 \%$ are in Ikeja, followed by Agege (10\%), Surulere (9\%), Lagos-Island (9\%), Somolu (8\%), Apapa (7\%), Oshodi-Isolo $(7 \%)$, Eti-Osa $(7 \%)$ and Kosofe $(6 \%)$ while the remaining Local Government Areas such as Mushin recorded (4\%), Amuwo-Odofin (4\%), Lagos-Mainland (4\%), Ojo (3\%), Alimoso (3\%) and Ifako-Ijaye $(3 \%)$. In a similar manner, the same nine Local Government areas also have dominant proportion of calls received in the area with Ikeja recording 14\%, followed by Oshodi (10\%), Somolu (10\%), Surulere (10\%), Eti-Osa (9\%), Agege (8\%), Apapa (8\%), Kosofe (8\%), and Lagos-Island $(6 \%)$, with the remaining six Local Government Areas such as Mushin recording 4\%, Amuwo-Odofin (4\%), LagosMainland (4\%), Ifako-Ijaye (3), Alimosho (3\%) and Ojo (2\%).

From the above, it can be deduced that calls are made and received mainly by the Local government Areas with the high concentration of commercial and industrial activities while the Local Government areas with low proportion of calls made and received have low level of industrial and commercial activities. 
Ethiopian Journal of Environmental Studies and Management EJESM Vol. 5 no.4 (Suppl.1) 2012

Table 5 Average daily cumulative number of calls to and from each Local Government in the Lagos metropolis

\begin{tabular}{|c|c|c|c|c|c|c|c|c|c|c|c|c|c|c|c|c|c|c|}
\hline \multicolumn{2}{|c|}{ Day 5 Friday } & \multicolumn{16}{|c|}{ Area from where calls are made day 5} & \multirow[b]{2}{*}{$\%$} \\
\hline \multirow{18}{*}{$\begin{array}{l}\text { Area } \\
\text { where } \\
\text { calls are } \\
\text { received }\end{array}$} & & $\mathrm{AG}$ & OJ & $\mathrm{AM}$ & $\mathrm{AL}$ & $\mathrm{AP}$ & ET & IF & IK & $\mathrm{KO}$ & LI & LM & OS & SO & MU & SU & Total & \\
\hline & $\overline{\mathrm{AG}}$ & 9 & 2 & 2 & 1 & & 2 & 2 & 2 & & 2 & & & 2 & 6 & 8 & 38 & 7.0 \\
\hline & OJ & & & & & & & & 1 & & & & & 2 & 2 & & 6 & 1.1 \\
\hline & AM & & & 6 & 4 & & 2 & & & & 4 & & 7 & 2 & & & 25 & 4.6 \\
\hline & AL & 2 & & & 2 & 2 & 3 & & 1 & & & & & 2 & & 2 & 14 & 2.6 \\
\hline & AP & & 4 & 2 & & 6 & 4 & & & & & 4 & 4 & 2 & 3 & 4 & 33 & 6.1 \\
\hline & ET & 2 & & & & & 13 & 3 & 9 & 5 & 3 & & 4 & 5 & & 6 & 50 & 6.3 \\
\hline & IF & 9 & 2 & & & & & & 5 & & 4 & & 2 & & & & 22 & 4.1 \\
\hline & IK & 8 & & 4 & & 1 & 9 & 5 & 18 & 2 & 4 & 7 & 10 & 7 & 4 & 7 & 86 & 15.9 \\
\hline & $\mathrm{KO}$ & 8 & 2 & & & 5 & 5 & & 8 & 8 & 2 & 2 & & 2 & 2 & & 44 & 8.1 \\
\hline & LI & 4 & 2 & & & 2 & & & 2 & 2 & 6 & 2 & 2 & 2 & & & 24 & 7.4 \\
\hline & LM & & & 2 & & 2 & 5 & & 4 & 2 & & 2 & & 2 & & 2 & 21 & 3.9 \\
\hline & OS & 2 & 2 & 7 & 3 & 2 & 2 & & 4 & 2 & & & 14 & & 2 & 4 & 44 & 8.1 \\
\hline & $\mathrm{SO}$ & 4 & & 6 & & 2 & 3 & & 4 & 9 & 2 & 2 & & 12 & 5 & 3 & 52 & 9.6 \\
\hline & MU & 2 & & & & 1 & 2 & & 6 & & 3 & & 2 & & 2 & & 17 & 3.1 \\
\hline & $\mathrm{SU}$ & 10 & & & & 2 & 8 & & 15 & 3 & & & 2 & 12 & 5 & 7 & 64 & 11.9 \\
\hline & Total & 60 & 14 & 29 & 10 & 26 & 58 & 10 & 79 & 33 & 29 & 19 & 47 & 52 & 31 & 43 & 540 & \\
\hline & $\%$ & 11.1 & 2.6 & 3.3 & 1.9 & 6.8 & 10.7 & 1.9 & 14.6 & 6.1 & 6.4 & 3.5 & 8.7 & 9.6 & 4.1 & 8.0 & & \\
\hline
\end{tabular}

Abbreviations: $\mathrm{AG}=$ Agege $; \mathrm{OJ}=\mathrm{Ojo} ; \mathrm{AM}=$ Amuwo-Odofin $; \mathrm{AL}=\mathrm{Alimoso} ; \mathrm{AP}-$ Apapa ET $=$ EtiOsa; IF = Ifako-Ijaye; IK = Ikeja; KO = Kosofe; LI = Lagos Island; LM = Lagos Mainland; OS = OshodiIsolo; $\mathrm{SO}=$ Somolu; $\mathrm{MU}=$ Mushin; $\mathrm{SU}=$ Surulere

Table 5 reveals the pattern of mobile phone usage among the residents of the fifteen Local Government Areas that constitute Lagos Metropolis. Going through where calls are made and received on day 5, (Friday), the pattern of mobile phone calls made shows that the highest proportion of calls made are in Ikeja with a record of (15\%), followed by Agege (11\%), Eti-Osa (11\%), Somolu (105), Oshodi-Isolo (9\%), Surulere (8\%), Apapa (7\%) and Kosofe (6\%) with the remaining Local Government Areas such as Mushin recording 4\%, Amuwo-Odofin (4\%), LagosMainland (4\%), Ojo (3\%), Alimoso (2\%) and Ifako-Ijaye (2\%).

Similarly, the same nine Local Government Areas also have the highest proportion of calls received in the area with Ikeja recording 10\%, followed by Surulere (11\%), Somolu (9\%), Oshodi-Isolo (8\%), Kosofe (8\%), Agege (7\%), Lagos-Island (7\%), Apapa (6\%) and Eti-Osa (6\%) with remaining six Local Government areas such as Lagos-Mainland accounting for 4\%, Amuwo-Odofin (4\%), Ifako-Ijaye (4\%), Mushin (3\%), Alimoso (3\%) and Ojo (1\%).

From the above, in the same manner, it could be observed that all calls are made and received mainly by the Local Government Areas with the high concentration of commercial and industrial activities while low proportion of calls are made and received in Local Government areas with low concentration of commercial and industrial activities. 
Table 6 Average daily cumulative number of calls to and from each Local Government in the Lagos metropolis

\begin{tabular}{|c|c|c|c|c|c|c|c|c|c|c|c|c|c|c|c|c|c|c|}
\hline \multicolumn{2}{|c|}{ Day 6 Saturday } & \multicolumn{16}{|c|}{ Area from where calls are made day 6} & \multirow[b]{2}{*}{$\%$} \\
\hline \multirow{17}{*}{$\begin{array}{l}\text { Area } \\
\text { where } \\
\text { calls are } \\
\text { received }\end{array}$} & & $\overline{\mathrm{AG}}$ & OJ & AM & $\mathrm{AL}$ & $\mathrm{AP}$ & ET & IF & IK & $\mathrm{KO}$ & LI & LM & OS & $\mathrm{SO}$ & MU & SU & Total & \\
\hline & $\mathrm{AG}$ & 2 & 2 & 3 & & & 2 & 4 & 3 & & & 4 & & & & & 20 & 7.7 \\
\hline & OJ & 1 & 4 & & & & & & 4 & 2 & & & 2 & & 2 & & 15 & 3.8 \\
\hline & $\mathrm{AM}$ & 2 & & & & 4 & & & & & 5 & & & & & 1 & 12 & 4.6 \\
\hline & $\mathrm{AL}$ & & & & & & & & 5 & & & & & & & & 5 & 1.9 \\
\hline & AP & 2 & & & & 5 & 1 & & 1 & 2 & & & 1 & & & 3 & 15 & 6.8 \\
\hline & ET & & & 2 & 2 & & 14 & 2 & 2 & 2 & & 2 & & 2 & 2 & 5 & 35 & 13.5 \\
\hline & IF & 2 & & & & & 2 & & 2 & & 2 & 2 & 2 & 2 & & & 14 & 4.4 \\
\hline & IK & 2 & & 5 & & 2 & 5 & & 2 & 4 & & & & 5 & & 4 & 29 & 11.2 \\
\hline & $\mathrm{KO}$ & & & & & & 2 & 2 & & & & 2 & 4 & & & 3 & 13 & 6.0 \\
\hline & LI & 2 & & & & & & & & & & 2 & 2 & 2 & & 3 & 11 & 6.2 \\
\hline & LM & & & & & & & & & 4 & 3 & 2 & & 3 & & 2 & 14 & 4.4 \\
\hline & OS & & & & & & & & 5 & & & 1 & 8 & 2 & 1 & & 17 & 6.6 \\
\hline & $\mathrm{SO}$ & & 1 & 4 & & & 4 & 2 & 1 & 2 & 4 & & & & & & 18 & 6.9 \\
\hline & $\mathrm{MU}$ & & & & & & 2 & & 2 & & 2 & & & & & 5 & 11 & 4.2 \\
\hline & SU & 2 & 2 & & & 2 & 7 & & 3 & 4 & 4 & & & & 2 & 4 & 30 & 11.6 \\
\hline & Total & 15 & 11 & 18 & 2 & 9 & 39 & 10 & 30 & 20 & 20 & 15 & 19 & 16 & 7 & 30 & 259 & \\
\hline & $\%$ & 6.8 & 4.2 & 2.9 & 0.8 & 7.5 & 15.1 & 3.9 & 12.6 & 7.7 & 7.7 & 3.8 & 7.3 & 6.2 & 2.7 & 11.6 & & \\
\hline
\end{tabular}

Abbreviations: $\mathrm{AG}=$ Agege OJ = Ojo; $\mathrm{AM}=$ Amuwo-Odofin $; \mathrm{AL}=$ Alimoso AP - Apapa $;$ ET = Eti-Osa; IF = Ifako-Ijaye; IK = Ikeja; KO = Kosofe; LI = Lagos Island; LM = Lagos Mainland; OS = Oshodi-Isolo; SO = Somolu; $\mathrm{MU}=$ Mushin; $\mathrm{SU}=$ Surulere

Table 6 shows the pattern of mobile phone usage among the residents of the fifteen Local Government Areas that constitute Lagos metropolis. Going through where calls are made and received on day six, (Saturday), the pattern of mobile phone calls reveals that the highest proportion of calls made are in Eti-Osa $(15 \%)$, followed by Ikeja (13\%), Surulere (12\%), Apapa (8\%), Agege (7\%), Kosofe (7\%), Lagos-Island (7\%), Oshodi-Isolo $(7 \%)$ and Somolu (6\%), with the remaining six Local Government areas such as Ojo recording (4\%), Lagos Mainland (4\%), Ifako-Ijaye (4\%), Mushin (3\%), Amuwo-Odofin (3\%) and Alimoso (1\%). In a similar manner, the same nine Local Governments Areas also have highest proportion of calls received in the area with Eti-Osa accounting for (14\%); followed by Surulere $(12 \%)$, Ikeja (11\%), Agege $(8 \%)$, Apapa (7\%), Oshodi-Isolo (7\%), Somolu (7\%), Kosofe $(6 \%)$ and Lagos-Island $(6 \%)$ with the remaining six Local Government areas such as Ojo recording (4\%), Amuwo-Odofin (4\%) Mushin (4\%), Lagos Mainland (4\%) IfakoIjaye (4\%) and Alimoso (2\%) indicating a low proportion of calls received.

From the above, in the same manner it could be inferred that all calls are made and received mainly by the Local Government areas with a high concentration of industrial and commercial activities while the Local Government Areas with low level of calls made and received have low concentration of commercial and industrial activities. 
Table 7 Average daily cumulative number of calls to and from each Local Government in the Lagos metropolis

\begin{tabular}{|c|c|c|c|c|c|c|c|c|c|c|c|c|c|c|c|c|c|c|}
\hline \multicolumn{2}{|c|}{ Day 7 Sunday } & \multicolumn{16}{|c|}{ Area from where calls are made day 7} & \multirow[b]{2}{*}{$\%$} \\
\hline \multirow{17}{*}{$\begin{array}{l}\text { Area } \\
\text { where } \\
\text { calls are } \\
\text { received }\end{array}$} & & $\mathrm{AG}$ & OJ & AM & $\mathrm{AL}$ & AP & ET & IF & IK & $\mathrm{KO}$ & LI & LM & OS & SO & MU & SU & Total & \\
\hline & $\mathrm{AG}$ & 2 & 2 & 1 & 3 & & 2 & & 4 & & & & & 2 & & & 16 & 14.5 \\
\hline & OJ & & 4 & & & & & & & & 2 & & 2 & & & & 8 & 4.1 \\
\hline & AM & & & 1 & & & & & 1 & & & & & & & & 2 & 1.8 \\
\hline & $\mathrm{AL}$ & & & & & & 1 & & & & & & 5 & & & & 6 & 4.5 \\
\hline & AP & 1 & & & & & 2 & & 2 & 2 & & & & & & & 7 & 6.4 \\
\hline & ET & & & & & 1 & 2 & & 2 & 3 & & & & & & & 8 & 7.3 \\
\hline & IF & & & & & & & & 2 & & 4 & & & & & & 6 & 3.5 \\
\hline & IK & 2 & & 2 & & & 2 & 4 & 1 & & & 2 & & 2 & & & 15 & 13.5 \\
\hline & $\mathrm{KO}$ & 2 & & & & & & & 3 & 2 & & & & & & & 7 & 6.4 \\
\hline & LI & & & & & 3 & & & & & & & 2 & & 2 & & 4 & 6.6 \\
\hline & $\mathrm{LM}$ & & & & & & & & & & & & & 3 & & & 3 & 2.7 \\
\hline & OS & & & 3 & & & & & & & 2 & & & 2 & & 2 & 9 & 8.2 \\
\hline & $\mathrm{SO}$ & & & 3 & & & & & 2 & & & & & & & & 5 & 6.5 \\
\hline & MU & 3 & & & & 10 & & & & & & & & & & & 3 & 2.7 \\
\hline & SU & & & & & & 2 & & 2 & & & & 2 & & & & 6 & 7.5 \\
\hline & Total & 10 & 6 & 10 & 3 & 14 & 11 & 4 & 24 & 7 & 8 & 2 & 11 & 9 & 2 & 12 & 110 & \\
\hline & $\%$ & 9.1 & 4.5 & 4.1 & 2.7 & 8.9 & 10.0 & 3.6 & 21.8 & 6.4 & 7.3 & 1.8 & 10.0 & 8.2 & 1.8 & 6.8 & & \\
\hline
\end{tabular}

Abbreviations: $\mathrm{AG}=$ Agege $; \mathrm{OJ}=\mathrm{Ojo} ; \mathrm{AM}=$ Amuwo-Odofin $; \mathrm{AL}=$ Alimoso AP - Apapa ET = Eti-Osa IF = Ifako-Ijaye; IK = Ikeja; KO = Kosofe; LI = Lagos Island; LM = Lagos Mainland; OS = Oshodi-Isolo; SO = Somolu; $\mathrm{MU}=$ Mushin; $\mathrm{SU}=$ Surulere

Table 7 shows the pattern of mobile phone usage among the residents of the fifteen Local Government Areas that constitute Lagos metropolis. Going through where calls are made and received on day 7 (Sunday), the pattern of mobile phone calls shows that highest proportion of calls made are in Ikeja with $22 \%$ followed by Oshodi-Isolo (10\%), EtiOsa (10\%), Agege (9\%), Apapa (9\%), Somolu $(8 \%)$, Surulere $(7 \%)$, Lagos Island $(7 \%)$ and Kosofe with the remaining Six Local Government Areas such as Ojo recording 4\%, Amuwo-Odofin (4\%), Ifako-Ijaye (4\%), Alimoso (3\%), Lagos-Mainland (2\%) and Mushin (2\%).

Similarly, the same nine Local Government Areas also have higher proportion of all calls received in the area with Agege accounting for
$15 \%$, followed by Ikeja (19\%), Oshodi-Isolo $(8 \%)$, Surulere $(7 \%)$, Eti-Osa (7\%), Apapa $(6 \%)$, Kosofe (6\%), Somolu (6\%), and LagosIsland $(6 \%)$ with the remaining six Local Government areas such as Ojo recording 4\%, Alimoso (4\%), Ifako-Ijaye (3\%), Lagos Mainland (3\%), Mushin (3\%) and AmuwoOdofin $(2 \%)$ indicating a least proportion of calls received in the area.

From the above, it could be inferred that all calls are made and received mainly by the Local Government Areas with a high level concentration of industrial and commercial activities while the low proportion of calls made and received are observed in the Local Government areas with low level concentration of industrial and commercial activities. 
Attempt is therefore further made in this section to examine summary of average cumulative of number of calls to and from each Local Government in Lagos metropolis and

Table 8 Average weekly cumulative number of calls to and from each Local Government in the Lagos metropolis

\begin{tabular}{|c|c|c|c|c|c|c|c|c|c|c|c|c|c|c|c|c|c|c|c|}
\hline \multicolumn{2}{|c|}{ Weekly } & \multicolumn{18}{|c|}{ Area from where calls are made in a week } \\
\hline \multirow{20}{*}{$\begin{array}{l}\text { Area } \\
\text { Where } \\
\text { Calls are } \\
\text { Received } \\
\text { in a } \\
\text { week }\end{array}$} & & AG & $\mathbf{O J}$ & $\mathbf{A M}$ & $\mathbf{A L}$ & $\mathbf{A P}$ & ET & IF & IK & KO & LI & LM & OS & SO & MU & SU & $\begin{array}{l}\text { Tota } \\
\text { l } \\
\text { Rece } \\
\text { ived }\end{array}$ & $\%$ & Mean \\
\hline & $\mathbf{A G}$ & 162 & 19 & 12 & 9 & 14 & 28 & 22 & 88 & 23 & 20 & 11 & 42 & 22 & 15 & 46 & 533 & 8.95 & 36 \\
\hline & OJ & 11 & 28 & 8 & 0 & 3 & 0 & 5 & 18 & 8 & 8 & 4 & 13 & 15 & 14 & 8 & 143 & 2.40 & 10 \\
\hline & AM & 18 & 6 & 36 & 9 & 17 & 12 & 6 & 15 & 9 & 15 & 10 & 27 & 10 & 2 & 14 & 206 & 3.46 & 14 \\
\hline & $\mathbf{A L}$ & 16 & 1 & 3 & 22 & 20 & 11 & 6 & 26 & 12 & 15 & 6 & 19 & 12 & 7 & 13 & 189 & 3.17 & 13 \\
\hline & $\mathbf{A P}$ & 13 & 12 & 11 & 4 & 57 & 42 & 8 & 22 & 20 & 11 & 22 & 24 & 30 & 22 & 21 & 319 & 5.35 & 21 \\
\hline & ET & 30 & 8 & 9 & 10 & 27 & 159 & 16 & 66 & 44 & 29 & 14 & 35 & 42 & 22 & 37 & 548 & 9.20 & 37 \\
\hline & IF & 18 & 4 & 4 & 6 & 7 & 12 & 12 & 28 & 12 & 17 & 11 & 19 & 10 & 4 & 2 & 166 & 2.79 & 11 \\
\hline & IK & 81 & 23 & 31 & 28 & 52 & 89 & 34 & 269 & 47 & 45 & 32 & 73 & 63 & 24 & 88 & 979 & 16.43 & 65 \\
\hline & KO & 38 & 16 & 13 & 6 & 21 & 33 & 13 & 62 & 78 & 15 & 18 & 22 & 46 & 24 & 26 & 431 & 7.23 & 29 \\
\hline & LI & 24 & 10 & 2 & 6 & 27 & 28 & 10 & 53 & 26 & 64 & 18 & 29 & 26 & 8 & 37 & 368 & 6.18 & 25 \\
\hline & LM & 13 & 6 & 11 & 3 & 2 & 28 & 4 & 44 & 11 & 30 & 47 & 15 & 20 & 10 & 22 & 266 & 4.46 & 18 \\
\hline & OS & 53 & 14 & 19 & 23 & 20 & 48 & 8 & 63 & 45 & 34 & 12 & 115 & 46 & 20 & 26 & 546 & 9.16 & 36 \\
\hline & SO & 33 & 12 & 20 & 7 & 19 & 35 & 13 & 60 & 35 & 29 & 15 & 30 & 87 & 20 & 47 & 462 & 7.75 & 31 \\
\hline & MU & 25 & 8 & 4 & 10 & 22 & 17 & 15 & 28 & 8 & 17 & 6 & 15 & 19 & 23 & 19 & 236 & 3.96 & 16 \\
\hline & SU & 46 & 13 & 6 & 16 & 32 & 40 & 12 & 99 & 35 & 36 & 18 & 48 & 30 & 33 & 102 & 566 & 9.50 & 38 \\
\hline & Total & 581 & 180 & 189 & 159 & 340 & 582 & 184 & 941 & 413 & 385 & 244 & 526 & 478 & 248 & 508 & 5958 & 100.00 & \\
\hline & Calls & & & & & & & & & & & & & & & & & & \\
\hline & $\%$ & 9.75 & 3.02 & 3.17 & 2.67 & 5.71 & 9.77 & 3.09 & 15.79 & 6.93 & 6.46 & 4.10 & 8.83 & 8.02 & 4.16 & 8.53 & & & \\
\hline & MEAN & 39 & 12 & 13 & 11 & 23 & 39 & 12 & 63 & 28 & 26 & 16 & 35 & 32 & 17 & 34 & & & \\
\hline
\end{tabular}

Abbreviations: $\mathrm{AG}=$ Agege; $\mathrm{OJ}=\mathrm{Ojo} ; \mathrm{AM}=$ Amuwo-Odofin; $\mathrm{AL}=$ Alimoso; $\mathrm{AP}-$ Apapa $; \mathrm{ET}=$ EtiOsa; IF = Ifako-Ijaye; IK = Ikeja; KO = Kosofe; LI = Lagos Island; LM Lagos Mainland; OS = OshodiIsolo; $\mathrm{SO}=$ Somolu; $\mathrm{MU}=$ Mushin; $\mathrm{SU}=$ Surulere

Table 10a Oneway : Calls Made. ANOVA Summary

\begin{tabular}{|l|l|c|l|c|c|}
\hline & Sum of Squares & df & Mean Square & F & Sig. \\
\hline Between Groups & 42744.293 & 14 & 3053.164 & 4.446 & .000 \\
Within Groups & 144217.9 & 210 & 686.752 & & \\
Total & 186962.2 & 224 & & & \\
\hline
\end{tabular}

Table 10b Oneway : Calls Received. ANOVA Summary

\begin{tabular}{|l|l|c|l|c|c|}
\hline & Sum of Squares & df & Mean Square & F & Sig. \\
\hline Between Groups & 45586.160 & 14 & 3256.154 & 4.837 & .000 \\
Within Groups & 141376.0 & 210 & 673.219 & & \\
Total & 186962.2 & 224 & & & \\
\hline
\end{tabular}


Table 10a and 10b represents the Analysis of Variance used to test significance difference of number of calls among the Local Government areas. The observed significance level (Sig. F \} is less than $0.05(5 \%)$, the hypothesis that there is no significant difference between the Local Government areas is rejected. In other words, the study concludes that there is a significant difference in the number of calls among the local government areas

\section{Conclusion}

The low level and high level of calls made and received could be contributed to distributional pattern and inadequate telephone facility among the urban centres in the Lagos metropolis. This has necessitated a situation in which interactions among the residents are more through transportation mode rather than through telecommunication mode. Another major reason is that of the nature of commercial transactions and more importantly socio-cultural background of the people which is still much in favour of physical contacts.

\section{References}

Abler, R.F. (1974), The geography of Communication - Transportation Geography: comments and reading. New York: McGrawhill Books Company.

Axhausen, K.W. and Garling T. (1992) "Activity Based Approach to Travel Analysis" Conceptual Framework, Models and Research Problem Transport Reviews, 12(4), 323-341.

Ayeni, B (1979), Concepts and Techniques in Urban Analysis Croom Helm Ltd, London.

Balogun, Yinka, Odunmosu, Tayo, and Ojo, kayode (1999), "Lagos State in Maps" Ibadan Rex Charles Publication.

Cherry, C. (1970), Human

Communication: Technology and Urban Planning in D.Jones (Ed), Communication and Energy in Changing Urban Environments, Pp. 117-130. Butterworths London.

Clark, D. (1973), "Communication and the Urban Future. A case study of Trunk
Telephone call patterns in Wales" Regional Studies, 7(3), 315-321.

Elliot-Hurst, M. E. (1974), Transportation Geography: Comments and Readings.

Filani, M.O. and Osayinmese, I.Z. (1979), "Intra-city Traffic Flow Problems in Nigeria" The Nigerian Geographical Journal, 22(1), 17-31.

Filani, M.O. (1991). Mobility Crisis in Nigeria Federal Government's Mass Transit Programme" Annals of the Social Science Council of Nigeria, 3, 13-30.

Filani, M.O. (1993), "Transport and Rural Development in Nigeria" Journal of Transport Geography, 1(4), 248-254.

Goddardd, J.B. (1970), Functional Regions within the City Centre: A study of factor analysis of Taxi flows in Central London". Institute of British Geographers Transaction 49, 161-182.

Mokhtavian, P.L. and I. Salomon (2002), Emerging travel patterns: Do telecommunications make a difference? In perpetual Motion: Travel behaviour Research Opportunities and Application Challenges, edited by H.S. Mahmassani: Oxford, U.K. Pergamon Press/Elsevier.

Oyesiku, O.O. (1990), "Inter-Urban travels pattern in Nigeria". A Case Study of Ogun State, (Unpublished Ph.D Thesis University of Benin City, Nigeria).

Oyesiku, O.O. (1995), “An Analysis of Demand for Later-city trip Generation Attributes of a Developing State in Nigeria in Journal of Transport Studies,11(1\&2), 12(1\&2), 112-130.

Oyesiku, O.O. (1996), Inter-City Travels and Telecommunications relationship: an Explorative Study in Nigeria" Journal of Ife Social Science pp. 37-49, University of Ife Press

Osoba, S. B. (2010), "Influence of Global system for Mobile communication on Intracity Travel in Lagos, Nigeria. Unpublished Ph.D Thesis, University of Ibadan. 